\title{
Currency carry trade and the cost of international reserves in Mexico
}

\author{
Carlos A. Rozo and Norma Maldonado ${ }^{1}$
}

\begin{abstract}
National strategies aimed at boosting economic growth following the global financial crisis have spawned monetary imbalances between industrial and emerging economies. By implementing ultra-expansionary monetary policies, the industrial economies drive down interest rates, while the emerging economies tighten their monetary policies by raising rates, thus generating a burgeoning foreign-currency carry trade. Vulnerability is caused by the sudden reversal of such capital flows or the high cost of insuring against this by accumulating reserves. This paper estimates that the cost of reserve accumulation between 2008 and 2014 averaged 1.83\% of GDP, so the free capital mobility espoused by the Mexican authorities makes it very costly to play by the rules of financial globalization.
\end{abstract}

\section{Keywords}

Capital movements, foreign exchange, foreign exchange markets, monetary reserves, costs, monetary policy, Mexico

\section{JEL classification}

F31, F32, F38

\section{Authors}

Carlos Antonio Rozo Bernal is a level-C tenured professor in the Department of Economic Production of the Autonomous Metropolitan University of Mexico. Email: rozo@correo.xoc.uam.mx.

Norma Maldonado is a research assistant in the Department of Economic Production of the Autonomous Metropolitan University of Mexico. Email: normamc_27@hotmail.com.

The authors are grateful for comments made by Mario Capdevielle Allevato and an anonymous referee, which helped improve the treatment of the topic. 


\section{Introduction}

National strategies to boost economic growth following the global financial crisis have spawned monetary imbalances between industrial and emerging economies. By implementing ultra-expansionary monetary policies, industrial countries drive interest rates down, thereby reducing the value of their currencies while making their export sectors more competitive. In contrast, emerging economies tighten their monetary policies by raising interest rates to attract capital. These conflicting policies have generated large interest-rate spreads, which attract capital flows into emerging markets.

This has led to a wide-ranging and growing foreign-exchange carry trade, which energizes and strengthens what Burnside, Eichenbaum and Rebelo (2011) identify as one of the oldest and most popular currency trading strategies. While this carry trade generates large profits for footloose short-term capital, it undermines well-being in emerging markets by creating vulnerability, owing to sudden reversals of these flows and the high cost of insuring against this by accumulating reserves.

The scale of this carry trade forced the International Monetary Fund (IMF) to recognize the validity of the reactions of a number of emerging country governments to defend themselves against short-term capital pressures with cross-border control policies. It was thus recognized that emerging countries did not have to pay for the dishes that the more developed countries had broken. IMF accepted that, under certain circumstances and conditions, these countries were entitled to use such policies to address the risks caused by hot-money inflows. Thus, it was accepted that controlling cross-border capital flows is legitimate and can be a useful part of a macroeconomic strategy to prevent such flows from affecting the value of the local currency, or at least mitigate the repercussions.

Mexico is one of the emerging markets whose exchange rate has come under heavy pressure from these capital flows. Other countries that have experienced a similar fate - and in some cases with greater pressures - have included, Brazil, Chile, Colombia and Peru, along with India, the Republic of Korea and Thailand. The difference between Mexico and the other affected countries reflects the attitude of the Mexican authorities, who do not consider it prudent or necessary to intervene to control the strengthening of the domestic currency, the peso, as other countries have done. The Mexican monetary authorities continue to deny that peso appreciation is harmful for the economy, so they consider it unnecessary to impose controls or, as IMF refers to them, exchange-rate management measures. This official stance is justified by the argument that the Mexican financial system is shielded against a sudden outflow of capital due to the accumulation of high levels of international reserves and the contracting of a Flexible Credit Line (FCL) with IMF.

This paper examines the rationale by which the Mexican authorities take a positive view of what the authorities of other countries consider harmful to their economies. It argues that the free capital mobility practised by the Mexican authorities reduces welfare among the Mexican people owing to the high cost of accumulating international reserves. To demonstrate this approach, sections II, III and IV review the grounds of the debate on the need for exchange controls that led the Fund to accept that certain types of measures, under certain conditions, are positive for emerging and developing countries. The study then analyses the behaviour of the exchange rate and how it relates to the monetary policy that gave rise to the Mexican super-peso. The following three sections (V, VI and VII) review the magnitude and return on capital flows, and the prevalence of short-term capital, Then, section VIII estimates the cost of the financial shielding, and the paper ends with conclusions. 


\section{Currency carry trade and exchange-rate protectionism}

The need to regain the growth momentum that was lost in the wake of the Great Recession has led industrial economies, particularly the United States, to implement a loose monetary policy that has forced the benchmark interest rate down to zero. The weak performance of financial investments in these economies has fuelled the transfer of huge amounts of capital to economies offering higher rates of return. In a search for yield, financial investors have flooded emerging-country money markets with private portfolio inflows since 2009.

These flows have tended to destabilize exchange rates. In industrial countries the general trend has been one of currency depreciation, while emerging country currencies have generally tended to appreciate. These exchange-rate movements have provided trade advantages to the former, while making the latter less competitive. Given these imbalances created by the monetary policy of industrial countries, the emerging countries usually respond by protecting their markets, which marks a new milestone in the development of the global crisis, as a window of exchange-rate protectionism opens. Gallagher (2011a) and Rodrik (2010) note that this confrontation means that the international economy is approaching the end of an era in global finance - the era of free mobility of speculative capital.

The wide spread between interest rates in the north and the south has created opportunities for the currency carry trade, that is, the strategy of borrowing funds denominated in a low-interest-rate currency (the funding currency) to be invested in financial securities denominated in higher-yielding currencies (the investment currency) (Burnside, Eichenbaum and Rebelo, 2011, Clarida, Davis and Pedersen, 2009). The operation seeks a fiduciary gain augmented by the possible appreciation of the investment currency, which pays the higher interest rate (Banco de México, 2010). Despite the risk that this entails, the evidence tends to show that the activity is profitable (see Brunnermeier, Nagel and Pedersen (2008), and Jordá and Taylor (2009)).

The theory of uncovered interest-rate parity states that in a frictionless and risk-neutral economy, the currency carry trade is not profitable because the gain obtained from the interest rate spread is offset by an equi-proportional depreciation in the investment currency. Although capital flows entering the country cause an immediate appreciation of the currency as the market overshoots, this is later reversed, and the currency ultimately depreciates (Fama, 1984; Dornbusch, 1976). In practice, however, by persisting over time, the foreign-currency carry trade violates these theoretical postulates, since the investment currency continues to appreciate, thereby rendering the activity profitable.

This problem, known as the "forward-premium puzzle", is associated with the risk of a crash because exchange rates take the stairs up and the elevator down, which means that this dynamic can generate an "exchange-rate bubble" in the long run. ${ }^{2}$ The premium is the price of crash risk.

The yield on the assets in which the speculators invest has two basic drivers: a positive average rate of return and negative skewness. The gain occurs in recognition of the liquidity that the carry trade provides to the investment economy, while the negative skewness stems from the investment currency's exposure to crash risk, by movements in the opposite direction in the spot and future exchange rate, or expected exchange rate. What needs to be stressed is that positive interest-rate spreads are associated with negative skewness in exchange-rate movements, which means that the yields of the currency carry trade implicitly involve crash risk (Brunnermeier, Nagel and Pedersen, 2008, p. 4). This occurs because of the asymmetric responses of investors to movements in the expected exchange rate. When exchange-rate movements lead to losses, these are amplified by the difficulties that speculators may experience in obtaining funding and the urgency of offloading the assets. This drives their prices down and thus exacerbates the funding and volatility problems.

\footnotetext{
2 For a literature review on the subject, see Engel (1996).
} 
The forward-premium puzzle gives an important theoretical insight into the way international financial markets work, by suggesting that the concept of rational expectations is not valid. It also suggests that the interest-rate spread is a poor guide to efficient resource allocation, owing to the volatility it imposes on future exchange-rate movements. This is a good example of market inefficiencies, suggesting the need for government intervention in the foreign-exchange market.

\section{Consequences of the carry trade}

This carry trade is not neutral for the value of the investment currency, because it causes it to appreciate, thereby constituting a failure of the efficient-markets hypothesis. The key argument for this appreciation trend is that large volumes of short-term capital tend to behave pro-cyclically; in other words, too much money enters in the growth phase of the business cycle and too much flows out in the downswing (Gallagher, 2011a and 2011b). These flows generate costs and distortions in the relationship between the domestic and external balance of the recipient countries.

It is not entirely clear how these equilibria occur, given the intense debate about the most appropriate exchange-rate regime to fulfil the objectives of resource balance and allocation in a globalization context. It is not clear whether the exchange rate should be totally fixed or totally flexible, or somewhere between these extremes, as Frankel (2003) argues. No less relevant in this debate is that the national authorities officially state that they are operating under a floating regime when, de facto, they practise a fixed or controlled regime, as Calvo and Reinhart (2000) aptly express in their concept of "fear of floating". There is also no certainty that the extreme options - total rigidity or total flexibility - will lead the market to benignly determine the appropriate level of the exchange rate for a particular country. Nonetheless, under the floating exchange-rate regime, which has been used by emerging markets since the mid1990s, the carry trade has undoubtedly grown astronomically.

In the debate that has arisen around exchange-rate protectionism, the argument put forward by Ffrench-Davis (2010) on the "neoliberal error" seems to be a sensible proposal. The error is to believe that any exchange-rate intervention goes against the market, when in fact two types of markets need to be distinguished. In the contemporary neoliberal monetarist approach, the market being favoured is the speculative credit market of short-term operators who only seek to maximize their rents. Under this rationale, the exchange rate responds more to variations in the capital account than to changes in the trade or current-account balance, which means that the exchange rate becomes a financial asset, as Keynes (2003) postulated.

In a correct approach, the appropriate market is that of the production of tradable and nontradable goods in a context of innovation and technological change. The equilibria being pursued, and the appropriate allocations, should foster the creation of productive wealth that satisfies social needs.

The neoliberal error is responsible for the extreme volatility of nominal exchange rates, since their level responds more to variations in capital movements than to flows of goods and services. Thus, with a flexible exchange rate, the economy is exposed to procyclical variations caused by the actions of foreign portfolio investment funds, so the exchange rate becomes volatile because of the conditions imposed by financial operators. This has adverse effects for the national economy, as noted by Ffrench-Davis, namely: (i) distortions in the evaluation of projects for resource allocation; (ii) greater promotion of speculative than productive investments; (iii) displacement of the production tradable goods that can be imported; and (iv) a reduction in export value-added.

These effects can distort a development strategy led by the production of non-traditional exports which generate externalities and interact with small and medium-sized enterprises (SMEs). For this purpose, Ffrench-Davis argues, it is better to use intermediate dirty-floating regimes or moving bands, 
since targeting the correct market requires coherent and selective market intervention. In this context, it is clear that capital movements that cause exchange-rate appreciation tend to make domestic economies less competitive, which constrains export growth and fuels imports.

As a result, emerging countries would be right to design and implement macroprudential policies to control the negative effects of the currency carry trade. The response has been to develop strategies to inhibit the entry of speculative capital and prevent their currencies from appreciating. The application of these schemes and the responses to such actions have given rise to a "currency war" environment (Pérez, 2010), in a struggle to obtain a more competitive place in international trade. Joseph Stiglitz (2010) has pointed out how negative this war can be, since all countries could lose out; so solutions need to be found.

Discourse and practices in the design and management of exchange-rate protection policies recently resurfaced in the face of the urgent need to mitigate or avoid the negative effects of short-term cross-border capital flows. The trigger for the confrontation is the asymmetry between the monetary policies of the developed economies and those of the emerging economies, when the latter struggle to protect the dynamism of their growth, which is undermined by the industrial countries' policies to cheapen their currencies and gain foreign exchange competitiveness to stimulate export-led growth. ${ }^{3}$

\section{Exchange-rate management}

In the 1970s, neoliberal market fundamentalist attitudes defended capital-account liberalization at all costs, by arguing that capital flows and their mobility make it possible for countries with limited savings to attract funding for productive investment projects, diversify investment risk, promote intertemporal trade and contribute to the development of financial markets (Ostry and others, 2010a and 2010b). Over time, the evidence has shown that capital market liberalization in developing countries has not gone hand-in-hand with economic growth, and that any such association is more feasible in countries that have attained a high level of institutional development (Gallagher, 2010a). In general, emerging countries are more vulnerable to the adverse effects of short-term capital flows, because investment inflows for less than a year only target economies with stable political-economic characteristics, simply to obtain the higher potential return available from the carry trade. When the spread that drives this trade narrows or disappears, the capital in question abruptly flows out in search of higher-yielding alternatives in other countries.

These sudden reversals in capital flows tend to complicate macroeconomic management and aggravate financial risks. From the macroeconomic perspective, the concern is that waves of capital inflows exert upward pressure on the national currency and cause both the nominal and the real exchange rate to appreciate. This in turn means that less competitive domestic producers face cheaper imports and more expensive exports on the international market. This can cause lasting damage in the economy's export sector, even if the capital inflows subsequently decrease or reverse.

From the standpoint of financial fragility, the concern is that excessive capital inflows can undermine financial stability due to increased external indebtedness and excessive exposure to foreign exchange risks. These factors can induce vigorous domestic credit expansions and asset price bubbles, with serious adverse effects in the event of a sudden reversal of the capital inflows (Ostry and others, 2010a and 2010b; De Gregorio, 2010; Gallagher, 2010b; López-Mejía, 1999; Magud and Reinhart, 2006; Gallagher and Coelho, 2010). Consideration should also be given to the costs of a sterilization policy and the constraints that may be imposed on fiscal policy. Hence the importance of IMF acceptance of the possible use of measures to control capital inflows.

\footnotetext{
3 Nonetheless, Bergsten argues that the Federal Reserve's quantitative-easing strategy does not constitute a market intervention, which is a curious way of perceiving national interests (Bergsten and Gagnon, 2012).
} 
In February 2010, the Fund recognized that regulations on cross-border capital flows can be useful and constitute a legitimate macroeconomic policy tool (Ostry and others, 2010a and 2010b; IMF, 2011a and 2011b). Subsequently, in December 2012, IMF (2012a and 2012b) officially propounded a new "institutional approach" on capital-account liberalization that nations can consider to avoid and mitigate exchange-rate volatility and avert financial crises. This position diverges dramatically from that accepted in the neoliberal era of the 1970s, and is closer to the positions adopted by John Maynard Keynes and Harry Dexter White in their debate between 1941 and 1945 that capital controls should be an essential part of the smooth functioning of the global monetary-financial system (Gallagher, 2011a).

For IMF, the priority when developing exchange-rate management policies should be based on measures that strengthen the countries' ability to absorb capital flows (IMF, 2011b). The principle is that countries need to be better prepared for the inflow of such capital and not impede its mobility, since it leads to the implementation of structural reforms that increase the capacity of domestic financial markets to process the corresponding flows.

The Fund distinguishes between different types of measure, according to whether or not they aim to prevent the free flow of capital. The capital flow management measures (CFMs) that control the flow of capital are the most relevant, because they can be used as substitutes for macroeconomic policies that are appropriate and necessary for developing economies, and may have negative externalities for other countries (IMF, 2011b, p. 6).

Capital flow management measures are also of two types: residency-based CFMs and nonresidency-based CFMs. The former, commonly referred to as capital controls, affect cross-border financial activity by discriminating on the basis of residency. These measures are more circumstantial in response to capital inflows. In contrast, the second type are prudential measures designed to ensure the resilience and soundness of financial institutions, such as capitalization ratios, loan-to-value ratios, limits on net open foreign exchange positions and limits on foreign-currency mortgages. These nonresidency-based measures also include some that are typically applied in the non-financial sector, such as minimum periods of stay or taxes on some types of investment. Non-residence-based measures do not have the same macroeconomic and multilateral effects as those that use a residency parameter, such as limiting currency appreciation or redirecting flows to other countries. The fundamental difference between these two types of measure is whether they directly or indirectly affect the free mobility of capital flows.

In the case of flows, it is firstly appropriate to use macroeconomic policies and, mainly, allow the exchange rate to strengthen, accumulate reserves or adjust the balance between fiscal and monetary policies. CFM measures should be applied only when the appropriate macroeconomic conditions exist, which means that the exchange rate is not undervalued, that reserves are more than sufficient, and that the economy is overheated, which makes it unwise to lower interest rates. CFM measures need to be complementary to a contractionary fiscal policy and consider the lags associated with the macroeconomic effects of fiscal consolidation. For IMF, the application of CFM measures should have a low priority to avoid affecting other countries that participate in a multilateral reference framework.

The change in the Fund's stance has been the result of a wide-ranging debate, since until recently postulating capital control policies was going against the basic neoclassical premise that emerging economies should free their capital accounts as part of a broad process of financial liberalization needed to stimulate economic growth and stability (Gallagher, 2010b). Nonetheless, IMF continues to uphold its traditional principle by insisting that the key thing is to avoid impediments to the free mobility of capital owing to the negative effect this may have on the countries that generate the funds in question, usually the industrial countries. Less relevant is the cost of maintaining this position by the recipient, generally emerging, countries. It is in this context of theoretical debate that this paper examines the support for free capital movements espoused and practised by the Mexican authorities. 


\section{Exchange-rate volatility and public policy in Mexico}

The appreciation of the peso from mid-2009 to April 2011 did not cause the Mexican authorities to support the control of speculative flows adopted by the authorities of other countries. The Mexican monetary authorities, particularly Banco de México and the Ministry of Finance and Public Credit (SHCP), continue to insist that peso appreciation is of no concern for the Mexican economy, so there is no need for exchange-rate management measures.

It has been argued that the exchange-rate flotation regime works correctly to absorb external shocks; and the official position is also that the exchange rate should not be used as policy tool. What should be done is to protect stability and ensure responsible public-finance management and prudent decision-making (Banco de México, 2013). The official position considers that the risks for the Mexican economy come mainly from the slowdown in the United States growth rate and, to a lesser extent, from fiscal uncertainty in some European countries. Moreover, exchange-rate appreciation is assumed to reflect the soundness of the fundamentals of the Mexican economy given its low inflation and competitive advantages, such as geographic location, a solid skills base, and low transport and logistics costs (Piz, 2011a and 2011b). Nor is it accepted that the advantage of the export sector depends on the exchange rate.

Banco de México (BANXICO) and SHCP have argued that policies based on CFM measures do not have a sustainable effect in the medium term; and that controls on capital flows are not appropriate for Mexico, since the country is at an advanced stage of financial deepening. Basically, the authorities view these capital flows as unmistakable evidence that the Mexican economy is moving in the right direction thanks to sound public-policy management. ${ }^{4}$ Nonetheless, the decisive factor in this official position is the shielding that the Mexican economy has available to absorb international turbulence, which is based on a policy of accumulation of international reserves and the credit line approved by IMF. This official position reflects the market fundamentalism with which the Mexican economy has been managed since the late 1980s, which is wholly consistent with the IMF view that countries should use exchange-rate management policies more to adapt their economies to receive the capital in question than to impede its entry.

The authorities' position is not shared by other sectors. A large part of the business community and domestic producers support diverging positions with a generalized view that the strength of the dollar is making foreign products cheaper in the domestic market and making export products more expensive. Various business organizations have urged the authorities to defend the competitiveness of industry and prevent the currency from appreciating, since, in their opinion, an over-strong currency causes loss of competitiveness with negative effects on exports from many sectors (Monroy, 2011).

What has been clear is that the views of business leaders and the monetary authorities regarding the effects of the appreciation of the domestic currency do not coincide; but what complicates the debate is that the peso appreciation does not seem to be an obstacle to export growth. It is therefore useful to identify the factors that could give rise to these different opinions on the effect of the nominal exchange rate and the real exchange rate on the economy, but mainly on the cost for Mexico of receiving these flows of footloose capital.

4 These positions stand in contrast to those adopted by the Central Bank of Australia, a developed country which, in the same period as Mexico, experienced a considerable currency carry trade and, consequently, a strong appreciation of its currency. The bank warns that the strength of the Australian dollar has created high risks for the economy, because manufacturing companies have lost competitiveness, with negative effects on employment (The Economist, 2012, p. 30). 


\section{The evolution of the super-peso}

Since the crisis of 1994, the Mexican peso has been extremely volatile, despite the fact that the country has been subject to various monetary and exchange-rate regimes. Figure 1 shows that, since the abandonment of the fully fixed exchange-rate regime of 12.50 pesos to the dollar in 1976, the nominal parity has lost value on a long-term basis. Between 1976 and 1994, this resulted from devaluations implemented under the logic of the fixed-but-adjustable exchange-rate regime. Starting in 1995, despite the shift towards a free-floating regime, the parity between the peso and the dollar has maintained its long-term depreciating trend in a context of greater volatility with short-term fluctuations.

Figure 1

Mexico: nominal exchange rate, 1976-2014

(Pesos per dollar)

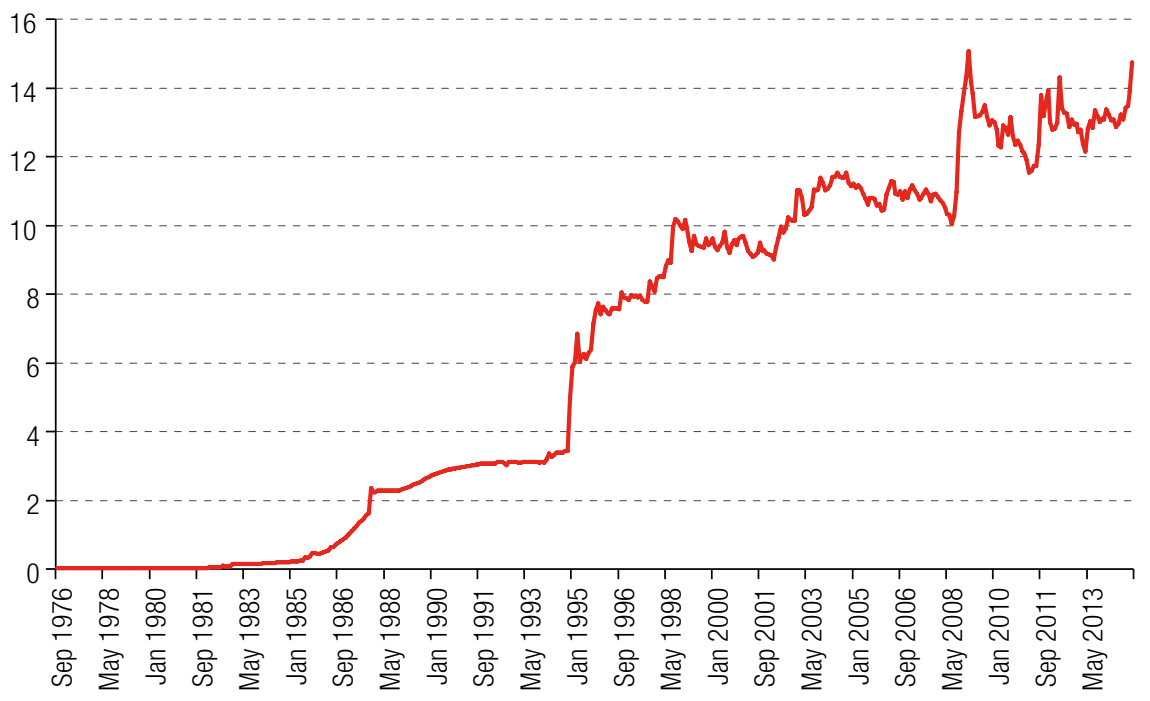

Source: Prepared by the authors, on the basis of data from Banco de México.

Figure 1 shows that, since the 2008 crisis, the nominal exchange rate has appreciated strongly: from 15.06 pesos per dollar in February 2009, the dollar price dropped to 11.52 in April 2011. This appreciation of $23.5 \%$ places the value of the peso in its mid-2004 range, but far from the levels of under 11 pesos per dollar that it experienced in mid-2008. The most that can be said is that this appreciation has returned the nominal value of the Mexican currency to the long-term trend imposed by the free-floating regime. Analysing the problem of the exchange rate exclusively from this perspective lends support to the Mexican authorities' belief that the exchange rate does not require management.

The long-term trend of nominal and real exchange rates (see figure 2), which spans the different periods of overvaluation and undervaluation experienced by the Mexican peso against the dollar since 1970, displays two clear features. The first is the divergence of these two trends: while the nominal exchange rate trends towards persistent long-term depreciation, the real exchange rate fluctuates cyclically between appreciations and depreciations. The key factor underlying these divergences is the pattern of Mexican inflation versus that of the United States. 
Figure 2

Mexico: trends in the real and nominal exchange rate, 1970-2014

(Mexican pesos)

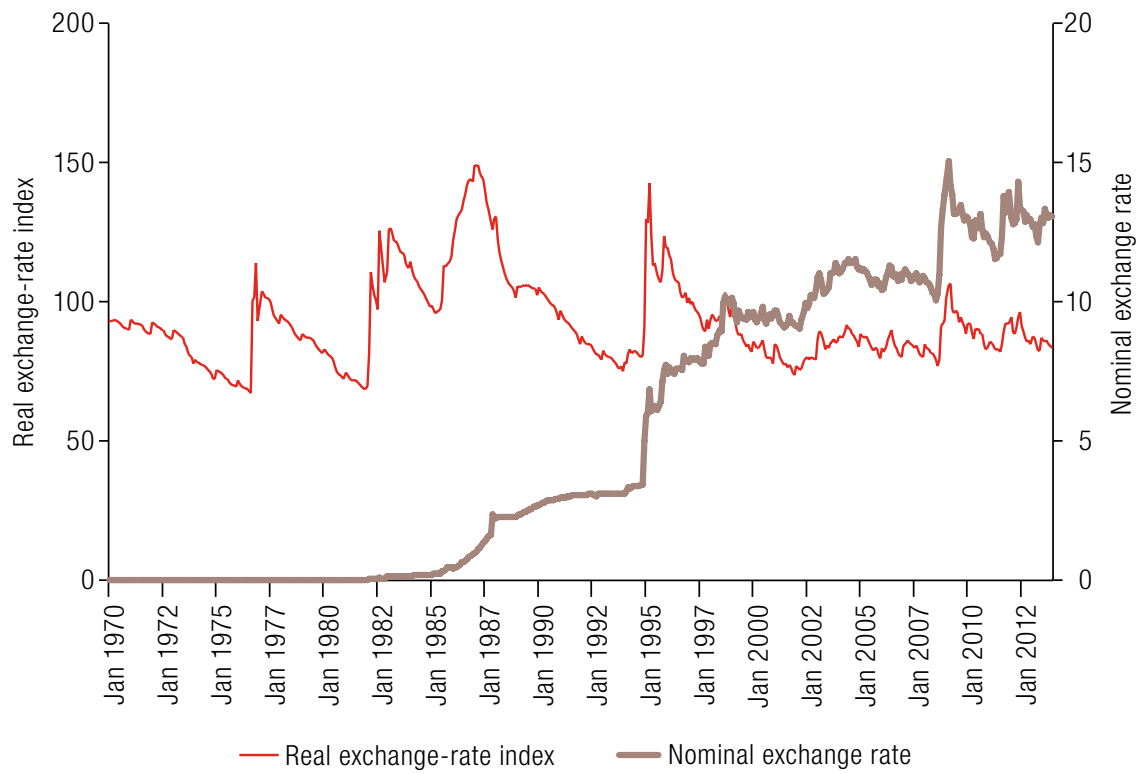

Source: Prepared by the authors, on the basis of data from Banco de México.

The second fact is that the Mexican economy has basically operated with an overvalued exchange rate for the last 40 years, except for brief periods of undervaluation: October 1976 to June 1977; March 1982 to October 1984; July 1985 to July 1990; January 1995 to January 1997; and in September and October 1998. From late 1998 to 2012, there was a persistent overvaluation, although with slight variations in degree.

Theoretically, having an open economy pursuing export-led growth means that Mexico should maintain a slightly undervalued exchange rate, to afford it greater competitiveness, which was first accepted as a principle of the exchange rate policy in the National Economic Development Plan of President Miguel de la Madrid Hurtado (1983-1988). This was consistent with the postulates of the Washington Consensus (Williamson, 1990; Kuczynski and Williamson, 2003). So it seems that Mexico has constantly swum against the tide in relation to the exchange rate, as explained below.

Figure 3 shows variations in the degree of overvaluation and undervaluation of the peso against the dollar between 1970 and 2012, making it possible to analyse the dynamics of the foreign-exchange market, based on the percentage difference between the nominal and real exchange rates relative to a given base year. Negative values indicate an undervaluation of the national currency against the dollar, and positive values represent an overvaluation, showing the degree of imbalance that has persisted in the exchange rate. From April 2009 to June 2012, the average monthly overvaluation was $7.2 \%$, and over a medium-term period (from January 2000 to February 2012), the overvaluation was $14.81 \%$ on average, although it peaked at 17.3\% in May 2011. These degrees of overvaluation are what determine the "super-peso" nature of Mexico's national currency.

An overvalued exchange rate makes foreign products cheaper in national currency relative to domestic products, owing to the increase in the purchasing power of foreign currency with respect to the local currency, and this fuels import growth. In contrast, an undervalued exchange rate reduces the purchasing power of the local currency relative to the foreign currency, making foreign products relatively more expensive than domestic products, which stimulates exports. 
Figure 3

Mexico: undervaluation and overvaluation of the Mexican peso, 1970-2014 (Percentages)

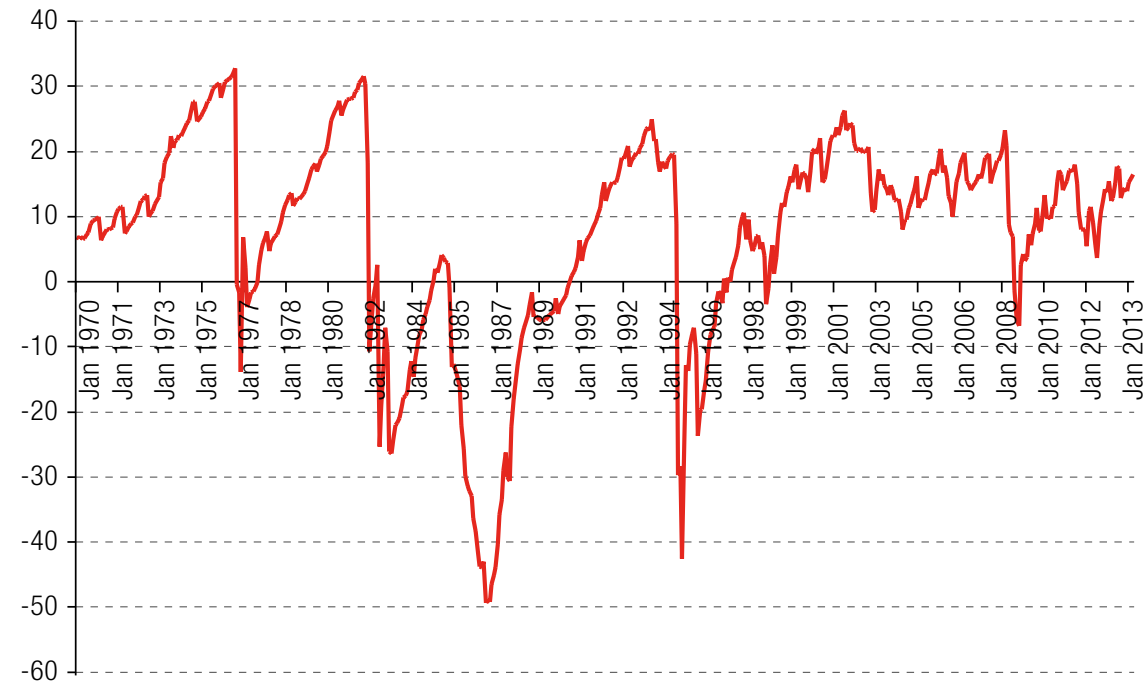

Source: Prepared by the authors, on the basis of data from Banco de México.

The steady growth of export and import flows, however, shows that the overvaluation of the Mexican peso has not impeded the success of the export policy. In fact, Mexico has become one of the world's leading exporters, shedding the mantle of a country that exports mainly primary products to become an exporter of manufactures. The evidence shows that, in the exchange-rate appreciation stage from March 2009 to March 2012, Mexican exports grew by $75 \%$ and imports by $66.2 \%$. From any perspective, these data suggest that the overvaluation of the peso does not undermine Mexican exports (Mold and Rozo, 2006; Rozo, 2009).

These observations show that in an economy that relies heavily on imported inputs, an overvalued exchange rate is not necessarily bad for exports. Overvaluation is convenient for the export activity on which Mexico's current development model is based, which is mainly undertaken by transnational corporations. This situation could explain the Mexican authorities' indifference to the exchangerate overvaluation.

So, should the exchange rate appreciation not be a cause for concern? The dilemma is that the nominal exchange rate appreciation experienced by the currencies of Mexico and other emerging countries does not merely reflect a temporary trade imbalance, but is the result of a large and rapid carry trade in speculative capital fuelled by a deliberate and long-term policy by industrial countries to speed up the economic recovery process through export activity, as shown in the next section. Such behaviour occurs regardless of the adverse effects that this may have on the trade competitiveness and growth and development capacities of emerging economies. To counter these pressures to hold investment currencies, the emerging economies have been forced to accumulate international reserves in record amounts. The real dilemma caused by these speculative capital inflows, which implies maintaining an exceptionally high level of reserves, is that they entail a high cost without evident benefits. 


\section{VII.Magnitude and yield of the capital flows}

The currency carry trade to Mexico is driven by the attractive return on government debt instruments. The spread between the secondary interest rates on Mexican government bonds and the rate on United States Treasury bonds is the key factor fuelling these speculative capital flows. To demonstrate this mechanism, the return $(R)$ can be measured by the formulation of the interest parity condition, in its simplest version:

$$
R=i-\left(i^{*}+(T C E-T C N) / T C N\right)
$$

where $i$ represents the local interest rate, $i^{*}$ is the foreign interest rate, TCE is the expected exchange rate and $T C N$ the nominal exchange rate. If $R$ is positive, it is worth investing in the local economy; if it is negative, it is better to invest abroad. When the yield is 0 , it is irrelevant which country is chosen, since the return is the same in both. To carry out this analysis of returns in the Mexican economy, the local short-term benchmark interest rate was used, represented by the yield on 28-day Treasury Certificates (CETES), in view of the growing demand for this type of government securities. The foreign interest rate is represented by the United States effective federal funds rate, and the change in parity is measured by the nominal peso per dollar exchange rate - FIX - published by the Banco de México. Figure 4 shows the average monthly yield between early 2007 and 2013, calculated applying the interest parity concept explained above.

\section{Figure 4}

Mexico: trend of yields, 2007-2014

(Percentages)

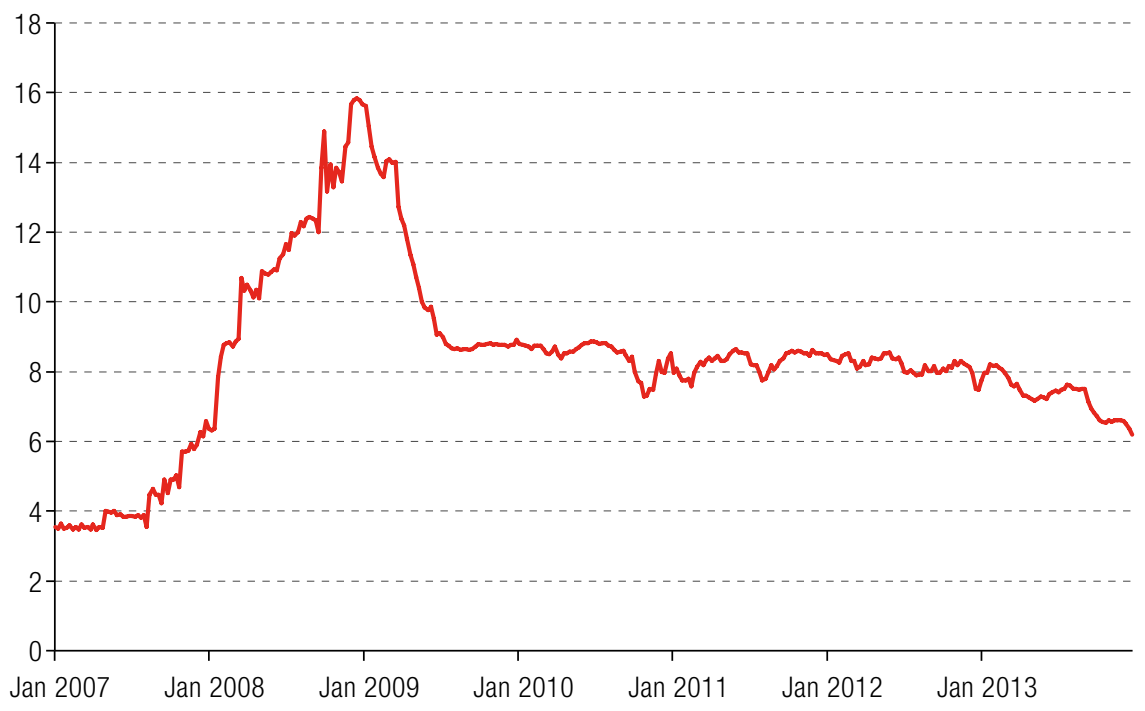

Source: Prepared by the authors, on the basis of data from Banco de México.

The slowdown in the United States economy and the subsequent subprime crisis in 2008 forced the effective federal funds rate down from 5.25\% in January 2007 to $0.25 \%$ in December 2008; and it was still at that level in mid-2015. Undoubtedly, this has encouraged speculative capital flight 
towards emerging markets; and Mexico in particular provides a haven, given its official open-door policy and the high yield on government debt. From January 2007 to December 2008, the fall in the effective federal funds rate in the United States raised the return in Mexico to a record level, reaching $15.84 \%$ on short-term debt instruments on December 18, 2008. Estimations made with short-term investment rationale show that the average rate of return of Mexican short-term debt instruments was 7.29\% in 2013, a significant reduction but still about three times the yield obtained in developed economies, of barely $2.5 \%$ according to data from the National Institute of Statistics and Geography (INEGI).

The higher yield obtainable in Mexico is what drives the large inflow of portfolio investment, as shown in figure 5. Between 2006 and 2008, these capital inflows behaved erratically with no defined trend; but from 2009 they display an unequivocal rapid growth path. The currency carry trade took off in late 2008, when the first phase of quantitative easing began (from November 2008 to March 2010), and it was consolidated with the second phase of the programme (November 2010 to June 2011). With the application of the third phase agreed on by the Federal Reserve on September 11, 2012, the high volume of speculative capital flows is maintained (see figure 6). In late 2008, non-residents held 251.114 billion pesos in Mexican government securities (11.7\% of the total) -but by the end of 2014 their holdings had grown to 1.53 trillion pesos or $38 \%$ of the total. These flows also reveal a structural change in the composition of foreign investment in Mexico. Until 2009, inflows of foreign direct investment (FDI) outweighed portfolio investment flows, the former totalling US\$17.331 billion, compared to the latter's US\$15.261 billion. The portfolio investment share of total foreign investment grew from 29.5\% in 2007 to $80.8 \%$ in 2012. Despite the approval of the structural reforms at the beginning of Enrique Peña Nieto's presidency, FDI inflows amounted to US\$38.285 billion in 2013 (39.8\% of the total foreign investment), while portfolio investment inflows amounted to US\$ 50.359 billion, or $60.8 \%$.

\section{Figure 5}

Mexico: comparison between the investment portfolio and the United States federal funds rate, 2006-2013

(Dollars and percentages)

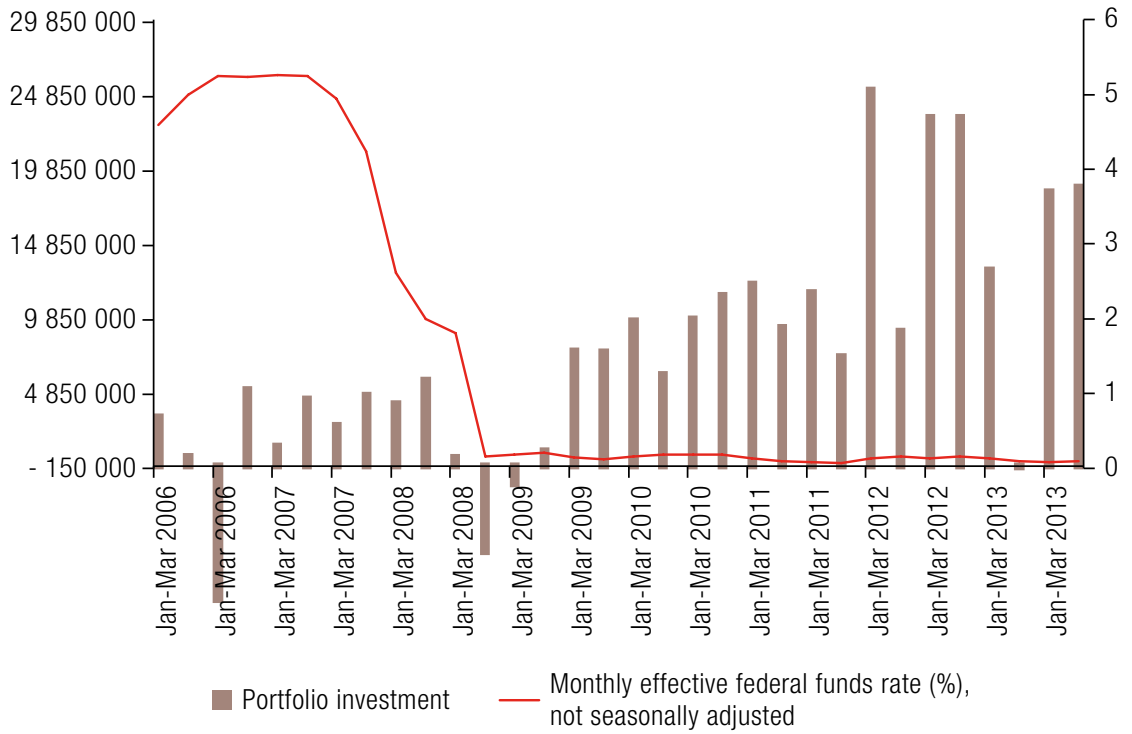

Source: Prepared by the authors, on the basis of data from Banco de México and the Federal Reserve. 
Figure 6

Mexico: trend of government securities, 2006-2014

(Billions of pesos)

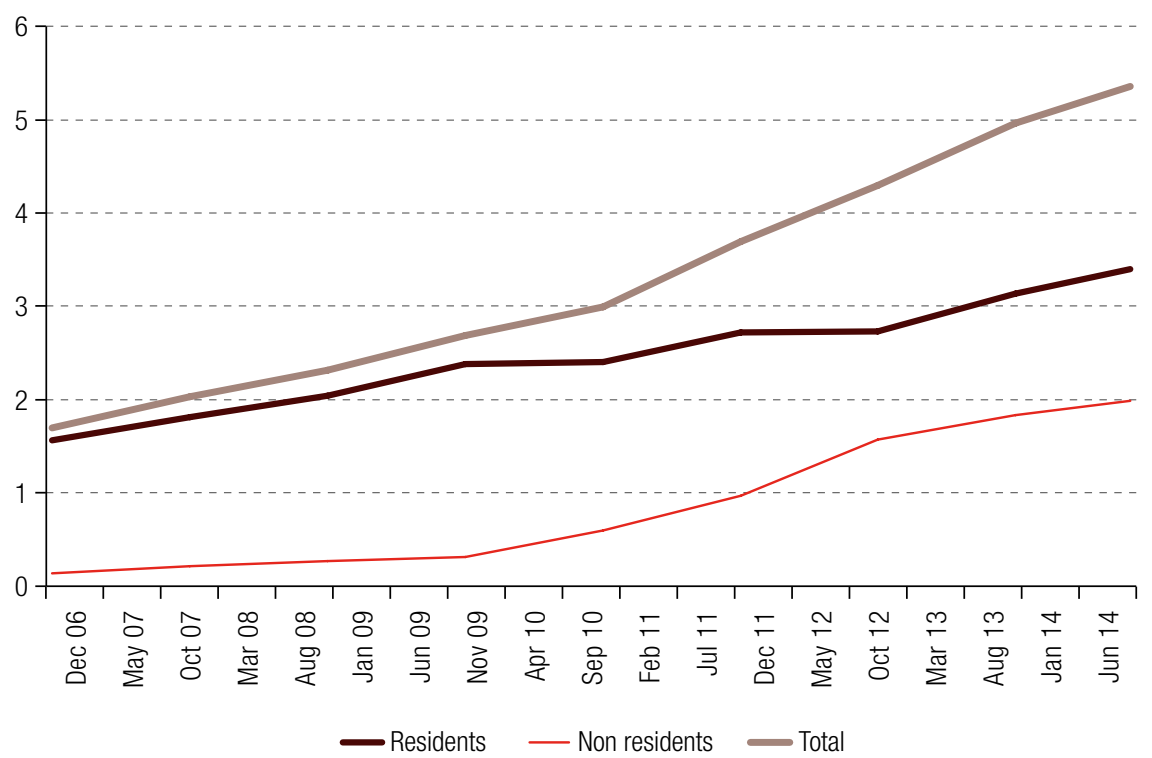

Source: Prepared by the authors, on the basis of data from Banco de México.

It should not be surprising, then, that the effective United States federal funds rate and shortterm investment flows into the Mexican economy were negatively correlated between 2006 and 2013. This means that, when the rate of United States interest falls, short-term foreign investment flows grow; so, as long as the United States economy maintains an ultra-expansive monetary policy with rock-bottom interest rates, yields in Mexico will continue to encourage the capital carry trade. High and secure returns are generating this flow of capital into Mexico, not the economy's sound fundamentals, as repeatedly claimed by the Mexican authorities. It also means that, when the Federal Reserve raises its interest rate, capital located in Mexico and other emerging markets will rapidly migrate to the United States, as occurred in early 2015, when a Federal Reserve interest rate hike seemed imminent towards the middle of the year. Since then, the United States economy has apparently not been able to make a robust and vigorous recovery, nor have the rest of the industrial countries; so the start of monetary policy normalization in the United States is likely to stay on hold.

Since 2010 Mexico has clearly become a highly attractive market for parking speculative capital, as a result of a public policy that encourages inflows by offering juicy and easy returns, backed by an open and explicit decision by the authorities not to impose restrictions on its earnings or stay in the country.

\section{The cost of financial armour}

Years ago, international reserves were used to manage the exchange rate that resulted from currentaccount supply and demand transactions; but today they manage the rate resulting from transactions on the capital account. This reflects the preponderance of financial globalization over commercial globalization; and what Peter Drucker (1986) has called the decoupling of the real economy from the financial economy is plain to see. 
The starting point in strategic reserves management is to recognize that Mexico has not joined the list of economies that worry about the effects of short-term cross-border capital flows. By refusing to manage the exchange rate, the Mexican authorities have defended the policy of exchange-rate flexibility as the only valid option; and they have backed this up with a preventive policy of reserve accumulation and IMF loans. The public policy option has been to shield the economy from the turbulence that may be generated by the permanency and outflow of capital. The strategy of shielding the Mexican economy began in April 2009, when the Banco de México asked IMF to approve a Flexible Credit Line (LCF) for SDR 31.528 billion, or roughly US\$ 47 billion, equivalent to 1,000\% of Mexico's quota in the Fund), for a period of 12 months. In March 2010, this LCF was renewed for an additional 12 months; and, although Mexico did not need to use the available funds, it was considered that LCF met the objective of generating confidence in financial markets (Comisión de Cambios, 2010a, 2010b and 2010c). In January 2011, credit line was approved once again, but this time for two years and for US\$ 72 billion $(1,500 \%$ of the quota). These changes were due to the heightened uncertainty prevailing in international economic activity (Comisión de Cambios, 2011). At that time, the appreciation of the peso caused by speculative capital inflows could not be ignored. This policy of international reserves accumulation had raised official reserve assets to an historical level of US\$195.682 billion at the end of 2014, which, in conjunction with LCF, imply financial shielding of US\$ 270 billion.

The problem with this course of action is that it has high costs and is untransparent; but scant mention is made of this. The monetary authorities prefer to emphasize that the Mexican economy is well prepared to provide the liquidity needed to mitigate a shock caused by sudden capital flight, with a level of constantly rising reserves; but the cost involved in this strategy goes unmentioned. If reserves are treated simply as a portfolio asset, without considering their financing or the corresponding obligations, their accumulation is seen as a net gain. But when the issue of financing is considered, the net financial result of holding reserves can entail a loss for the country (Nugée, 2004; Rodrik, 2006).

There are at least four types of costs in reserve accumulation: the opportunity cost; the financial or sterilization cost; the balance sheet cost and the cost arising from a lack of incentives (Flores, 2010; Santaella, 2010; Cruz, 2006). Rodrik argues that there is also a social opportunity cost of public capital, which is what should be considered when analysing the cost of providing armour plating to an economy by accumulating liquid assets in the form of international reserves. Rodrik estimated that in 1995-2004 the cost of such reserve accumulation rose from $0.002 \%$ to nearly $1 \%$ of the GDP in developing countries (Rodrik, 2006).

This study estimates the financial and opportunity costs of accumulating reserves in Mexico. The financial cost is defined as the spread between the return on assets, in this case gross international reserves, and the cost of the liabilities represented by the monetary base and by monetary regulation deposits, as shown in table 1. The opportunity cost is defined as the difference between the return on assets and the cost of the external debt of the Federal Government, as presented in table 2. The cost analysis must be based on appropriate yield levels. Data from Santaella (2010) show that international reserve assets provided a return of $0.9 \%$ in 2009 , while liabilities cost $5.75 \%$. At first glance, there is a clear spread between these rates of close to 485 basis points.

The return on international reserve assets was low between 2008 and 2012 as a result of the extraordinary fall in the discount rate on first-tier instruments in which international reserves are invested, such as United States Treasury bonds. In contrast, liabilities are much more expensive, despite also decreasing over the same period. At first sight it is clear that the Mexican authorities have paid a higher cost to finance the reserves than the yield they obtain from them; and this cost has grown over time, from US\$13.905 billion in 2009 to US\$17.306 billion in 2013, although the amount was lower in 2014. 
Table 1

Mexico: financial cost of accumulating international reserves, 2008-2014

\begin{tabular}{|c|c|c|c|c|c|c|c|c|c|c|c|}
\hline \multirow[b]{3}{*}{ Unit } & \multicolumn{3}{|c|}{ Assets } & \multicolumn{6}{|c|}{ Liabilities } & \multirow{3}{*}{$\begin{array}{l}\text { Financial cost: } \\
\text { differential } \\
\text { between the yield } \\
\text { of the asset and } \\
\text { the cost of the } \\
\text { liabilities } \\
\text { (US\$ million) }\end{array}$} & \multirow{3}{*}{$\begin{array}{l}\text { Percentage } \\
\text { of GDP }\end{array}$} \\
\hline & \multirow{2}{*}{$\begin{array}{c}\text { Gross } \\
\text { international } \\
\text { reserves } \\
\text { (US\$ } \\
\text { million) }\end{array}$} & \multicolumn{2}{|c|}{ Yield } & \multirow{2}{*}{$\begin{array}{l}\text { Bonds and } \\
\text { monetary } \\
\text { regulation } \\
\text { deposits } \\
\text { (US\$ million) }\end{array}$} & \multicolumn{2}{|c|}{ Yield } & \multirow{2}{*}{$\begin{array}{c}\text { Monetary } \\
\text { base } \\
\text { (US\$ } \\
\text { million) }\end{array}$} & \multicolumn{2}{|c|}{ Yield } & & \\
\hline & & $\begin{array}{l}\text { Rate } \\
(\%)^{a}\end{array}$ & $\begin{array}{c}\text { (US\$ } \\
\text { million) }\end{array}$ & & $\begin{array}{l}\text { Rate } \\
(\%)^{c}\end{array}$ & $\begin{array}{l}\text { (US\$ } \\
\text { million) }\end{array}$ & & $\begin{array}{l}\text { Rate } \\
(\%)^{c}\end{array}$ & $\begin{array}{c}\text { Yield } \\
\text { (US\$ } \\
\text { million) }\end{array}$ & & \\
\hline Dec 2008 & 95302 & 2.00 & 1910 & 219830 & 7.82 & 17180 & 41753 & 0 & 0 & -15270 & 1.72 \\
\hline Dec 2009 & 99893 & 0.96 & 956 & 264385 & 5.62 & 14861 & 48373 & 0 & 0 & -13905 & 1.50 \\
\hline Dec 2010 & 120587 & 0.70 & 847 & 305433 & 4.59 & 14030 & 56149 & 0 & 0 & -13182 & 1.23 \\
\hline Dec 2011 & 149209 & 0.45 & 674 & 324814 & 4.48 & 14549 & 54740 & 0 & 0 & -13875 & 1.33 \\
\hline Dec 2012 & 167050 & 0.28 & 462 & 397509 & 4.49 & 17845 & 65250 & 0 & 0 & -17383 & 1.44 \\
\hline Dec 2013 & 180200 & 0.31 & 554 & 448272 & 3.98 & 17860 & 70151 & 0 & 0 & -17306 & 1.40 \\
\hline Dec 2014 & 195682 & 0.49 & 960 & 438748 & 3.22 & 14139 & 72103 & 0 & 0 & -13178 & 1.14 \\
\hline
\end{tabular}

Source: Prepared by the authors, on the basis of data from Banco de México.

a Rate of return on the assets in which international reserves are invested (annual average rate of two-year United States Treasury bonds).

b Refers to total government securities and IPAB securities in circulation.

c Reference rate (annual average bank funding rate): representative rate of wholesale transactions carried out by banks and brokerages in spot and one-day repo transactions with certificates of deposit, bank promissory notes and bank acceptances that have been settled in the delivery-versus-payment system of the Institute for the Deposit of Securities (INDEVAL).

Table 2

Mexico: opportunity cost of holding international reserves, 2008-2014

\begin{tabular}{|c|c|c|c|c|c|c|c|c|}
\hline \multirow{3}{*}{ Unit } & \multicolumn{3}{|c|}{ Assets } & \multicolumn{3}{|l|}{ Liabilities } & \multirow{3}{*}{$\begin{array}{l}\text { Opportunity cost: } \\
\text { differential between } \\
\text { its yield and the cost } \\
\text { of gross public-sector } \\
\text { external debt } \\
\text { (US\$ million) }\end{array}$} & \multirow{3}{*}{$\begin{array}{l}\text { Percentage } \\
\text { of GDP }\end{array}$} \\
\hline & \multirow{2}{*}{$\begin{array}{l}\text { Gross } \\
\text { international } \\
\text { reserves } \\
\text { (US\$ million) }\end{array}$} & \multicolumn{2}{|c|}{ Yield } & \multirow{2}{*}{$\begin{array}{l}\text { Gross public- } \\
\text { sector external debt } \\
\text { (US\$ million) }\end{array}$} & \multicolumn{2}{|c|}{ Cost } & & \\
\hline & & $\begin{array}{l}\text { Rate } \\
(\%)^{\mathrm{a}}\end{array}$ & $\begin{array}{c}\text { Yield } \\
\text { (US\$ } \\
\text { million) }\end{array}$ & & $\begin{array}{l}\text { Rate } \\
(\%)^{b}\end{array}$ & $\begin{array}{c}\text { Yield } \\
\text { (US\$ } \\
\text { million) }\end{array}$ & & \\
\hline Dec 2008 & 95302 & 2.00 & 1910 & 56939.00 & 6.90 & 3929 & -2019 & -0.23 \\
\hline Dec 2009 & 99893 & 0.96 & 956 & 96354.00 & 5.09 & 4904 & -3949 & -0.43 \\
\hline Dec 2010 & 120587 & 0.70 & 847 & 110428.00 & 4.13 & 4561 & -3714 & -0.35 \\
\hline Dec 2011 & 149209 & 0.45 & 674 & 116420.00 & 5.59 & 6508 & -5834 & -0.56 \\
\hline Dec 2012 & 167050 & 0.28 & 462 & 125726.00 & 3.62 & 4551 & -4089 & -0.34 \\
\hline Dec 2013 & 180200 & 0.31 & 554 & 134436.00 & 2.60 & 3493 & -2939 & -0.24 \\
\hline Dec 2014 & 195682 & 0.49 & 960 & 147665.80 & 3.26 & 4814 & -3854 & -0.33 \\
\hline
\end{tabular}

Source: Prepared by the authors on the basis of data from Banco de México and the Secretariat of Finance and Public Credit.

a Rate of return on the assets in which international reserves are invested (annual average rate of two-year United States Treasury bonds).

b Fixed interest rate of federal government bond issuances on the international capital markets.

The trend of the opportunity cost is more uneven, as can be seen in table 2, because in 2008 the assets were obtaining a high yield from the positive interest rates that still existed on financial markets; but rates subsequently plummeted to $0.31 \%$ in 2013 , which caused these yields to decline gradually from US\$1.919 billion in 2008 to US\$ 554 million in 2013, although a higher yield was obtained in 2014 .

The cost of liabilities also decreased, as the rate fell from 6.9\% in 2008 to 3.26\% in 2014. Nonetheless, the cost of these liabilities in absolute terms rose from US\$ 3.929 billion to US\$ 5.834 billion between 2008 and 2011. This constant growth in the opportunity cost of holding reserves reflects the fact that their volume practically doubled between 2008 and 2011. This cost trended down in the ensuing years to reach US $\$ 2.939$ billion in 2013 as a result of the sharp fall in the rate of return, but it then rebounded in 2014 . The relevant fact is that the opportunity cost has also grown gradually during 
these years, although by much less than the financial cost in absolute terms. These differences are fully captured by calculating the costs relative to gross domestic product (GDP) (see table 3). In these years the average annual financial cost was equivalent to $1.39 \%$ of GDP, while the average annual opportunity cost was $0.35 \%$ of GDP.

Table 3

Mexico: total cost of international reserves with respect to GDP, 2008-2014

(Percentages)

\begin{tabular}{lcccc}
\hline Year & Financial & Opportunity & LCF & Total \\
\hline 2008 & 1.72 & 0.23 & & 1.95 \\
\hline 2009 & 1.50 & 0.43 & 0.12 & 2.05 \\
\hline 2010 & 1.23 & 0.35 & 0.10 & 1.68 \\
\hline 2011 & 1.33 & 0.56 & 0.10 & 1.99 \\
\hline 2012 & 1.44 & 0.34 & 0.09 & 1.87 \\
\hline 2013 & 1.40 & 0.24 & 0.09 & 1.73 \\
\hline 2014 & 1.14 & 0.33 & 0.09 & 1.56 \\
\hline Average & 1.39 & 0.35 & 0.10 & 1.83 \\
\hline
\end{tabular}

Source: Prepared by the authors.

To obtain a closer approximation to the cost of holding this level of reserves, the financial and opportunity cost must be augmented by the cost of contracting the IMF flexible credit line, which has an annual premium of US\$1.08 billion. The total cost of financial shielding thus varied between $2.05 \%$ and $1.57 \%$ of GDP, and averaged $1.83 \%$ of GDP in these six years.

Like Rodrik, we consider this level of costs to be very high, regardless of the measure used. Suffice it consider that this amount far outweighs any of the anti-poverty programs that have been implemented in developing countries. For example, the Progresa programme in Mexico had an approximate cost of barely $0.02 \%$ of GDP in 2001, its last year of operation; and the Oportunidades programme, which replaced it, cost roughly $0.42 \%$ of GDP in 2010. In 2011, the financial shielding afforded by the accumulation of international reserves amounted to about 10 times the budget allocated to Oportunidades; and, as if that were not enough, it is equivalent to four times the budget of the Social Development Secretariat, which is tasked with combating poverty. Rodrik concludes that developing nations are paying a very high price to play by the rules of financial globalization (2006, p. 9).

The most serious aspect of this situation is the lack of evidence for the supposed benefits of this short-term borrowing. It is supposed to foster better financial intermediation, promote greater local investment and create greater risk-sharing opportunities; but this does not seem to be happening, given the low level of bank credit portfolios, which grew from 19\% to 27\% of GDP between 2000 and 2014 (CNBV, 2014, p. 16). As a result, a policy of accumulating reserves to deal with the accumulation of short-term liquid liabilities does not seem to make sense, since the main benefit is apparently a lengthening of debt maturities, which has allowed for a settlement horizon of longer than one year for about $80 \%$ of the debt.

A more appropriate and much less expensive policy would be to reduce exposure to short-term debt, as IMF itself has finally recognized - especially when Mexico's reserves far exceed adequacy indicators in respect of trade, debt and the money supply. Mexico's net international reserves represent $40 \%$ of annual imports, compared to the traditional $25 \%$ or three months' imports. Moreover, the Guidotti-Greenspan rule for the level of international reserves, which posits that countries should hold liquid reserves in an amount equal to their external liabilities falling due within a year (Rodrik, 2006, p. 5), would recommend reserves at just $60 \%$ of their current level. 


\section{Conclusions}

There is unequivocal evidence that the global crisis caused by the excesses of the United States mortgage sector spawned national economic policy practices that are inconsistent with the requirements of global stability. High unemployment and low levels of aggregate demand caused industrial countries to relax their monetary policies to an extent that would be unthinkable in normal conditions, but were made reality by the conditions of hardship experienced in these last five years. These loose monetary policies have given rise to an environment of exchange-rate volatility caused by the currency carry trade that has spread between industrial countries and developing countries - a situation leading to what is metaphorically referred to "a currency war". What averted this war and has provided an opportunity to ease tensions is the IMF recognition that, in the current conditions of the world economy, some capital flow management practices are acceptable and positive for the stability of emerging markets.

Although Mexico has been one of the countries most affected by the carry trade, and given the latter's effect on domestic currency appreciation, the authorities have totally ruled out the use of the exchange-rate management tools a number of emerging economies have implemented. This has partly been the result of the market fundamentalism with which the Mexican economy has been run since the late 1980s, which is entirely consistent with the traditional position of IMF that countries should use CFM policies more to adapt their economies to receive such capital, than to prevent its entry. This official attitude is also a consequence of the limited effect that Mexican peso appreciation has had on the economy's export dynamics. What remains unclear clear is how the Mexican economy benefits from the entry and presence of short-term capital. What is clear, however, is that this reserve accumulation policy imposes a cost on the Mexican people that has averaged about 2\% of GDP per year in 2009-2014. By any measurement standard, this seems a very high cost to pay to insure against an unlikely event, such as sudden capital flight, considering the amounts and the expected timeframes for the normalization of monetary policy by the Federal Reserve. To quote Rodrik, we conclude that Mexico is paying a very high price to play by the rules of financial globalization.

\section{Bibliography}

Banco de México (2013), Reporte sobre el sistema financiero, Mexico City, September.

(2010), "Reporte sobre el sistema financiero. Junio de 2010", Mexico City [online] http://www.banxico. org.mx/publicaciones-y-discursos/publicaciones/informes-periodicos/reporte-sf/\%7BDC37ABCB-26F0020D-145B-5CF397D62E68\%7D.pdf.

Bergsten, C. F. and J. E. Gagnon (2012), "Currency manipulation, the US economy, and the global economic order”, Policy Brief, No. PB12-25, Washington, D.C., Peterson Institute of International Economics.

Brunnermeier, M. K., S. Nagel and L. H. Pedersen (2008), "Carry trade and currency crashes", NBER Working Paper, No. 14473, Cambridge, Massachusetts, National Bureau of Economic Research (NBER).

Burnside, C., M. S. Eichenbaum and S. Rebelo (2011), "Carry trade and momentum in currency markets", NBER Working Paper, No. 16942, Cambridge, Massachusetts, National Bureau of Economic Research (NBER).

Calvo, G. and C. Reinhart (2000), "Fear of floating”, NBER Working Paper, No. 7993, Cambridge, Massachusetts, National Bureau of Economic Research (NBER).

Clarida, R., J. Davis and N. Pedersen (2009), "Currency carry trade regimes: beyond the Fama regression", NBER Working Paper, No. 15523, Cambridge, Massachusetts, National Bureau of Economic Research (NBER).

CNBV (National Banking and Securities Commission) (2014), Ahorro financiero y financiamiento en México. Cifras a junio 2014, Mexico City.

Comisión de Cambios (2011), "El director ejecutivo del FMl aprobó hoy la línea de crédito flexible de alrededor de 72 mil millones de dólares para México por dos años", Mexico City. 
(2010a), "La Comisión de Cambios anuncia que se subastarán mensualmente opciones para vender dólares al Banco de México", Comunicado, Mexico City [online] http://calderon.presidencia.gob.mx/2010/02/ la-comision-de-cambios-anuncia-que-se-subastaran-mensualmente-opciones-para-vender-dolares-albanco-de-mexico/.

(2010b), "Circular 8/2010. Asunto: subastas para la celebración de opciones de venta de dólares de los Estados Unidos de América", Mexico City, Banco de México.

(2010c), "El Fondo Monetario Internacional renovó formalmente la línea de crédito flexible que tiene México", Comunicado de Prensa, Mexico City, Banco de México.

Cruz, M. (2006), "¿Pueden las reservas internacionales contribuir al crecimiento económico?, Economía UNAM, No. 8, vol. 3, Mexico City, National Autonomous University of Mexico.

De Gregorio, J. (2010), "Regulación macroprudencial, estabilidad financiera y flujos de capital", Documentos de Política Económica, No. 37, Santiago, Central Bank of Chile.

Dornbusch, R. (1976), "Expectations and exchange rate dynamics", Journal of Political Economy, vol. 84, No. 6.

Drucker, P. (1986), "The changed world economy", Foreign Affairs, vol. 64, No. 4.

Engel, C. (1996), "The forward discount anomaly and the risk premium: a survey of recent evidence", Journal of Empirical Finance, vol. 3, No. 2, Amsterdam, Elsevier.

Fama, E. F. (1984), "Forward and spot exchange rates", Journal of Monetary Economics, vol. 14, No. 3, Amsterdam, Elsevier.

Ffrench-Davis, R. (2010), "Macroeconomics for development: from 'financierism' to 'productivism', CEPAL Review, No. 102 (LC/G.2468-P), Santiago, Economic Commission for Latin America and the Caribbean (ECLAC).

Flores, L. A. (2010), "Costos de altas reservas internacionales", El Economista [online] http://eleconomista. com.mx/mercados-estadisticas/2010/06/29/costos-altas-reservas-internacionales.

Frankel, J. (2003), "Experience of and lessons from exchange rates regimes in emerging economies", NBER Working Paper, No. 10032, Cambridge, Massachusetts, National Bureau of Economic Research (NBER).

Gallagher, K. (2011a), "Regaining control? Capital controls and the global financial crisis", PERI Working Paper, No. 250, Amherst, Massachusetts, Political Economy Research Institute.

(2011b), "Reforming United States trade and investment treaties for financial stability: the case of capital controls", Investment Treaty News, Art. 3, No. 3, International Institute for Sustainable Development.

(2010a), "Control that capital", Foreign Policy [online] http://www.ase.tufts.edu/gdae/Pubs/rp/ GallagherFPCapControl.pdf.

(2010b), "Policy space to prevent and mitigate financial crises in trade and investment agreements", G-24 Discussion Paper Series, No. 58, New York, United Nations.

Gallagher, K. and B. Coelho (2010), "Capital controls and 21st century financial crises: evidence from Colombia and Thailand", PERI Working Paper, No. 213, Amherst, Massachusetts, Political Economy Research Institute.

IMF (International Monetary Fund) (2012a), "Liberalizing capital flows and managing outflows", Policy Papers, Washington, D.C., March.

(2012b), "The liberalization and management of capital flows: an institutional view", Policy Papers, Washington D.C., November.

(2011a), "Statement by the Managing Director on recent experiences in managing capital inflows. Crosscutting themes and possible policy framework", Washington, D.C., March.

(2011b), "Recent experiences in managing capital inflows, cross-cutting themes and possible policy framework", Policy Paper, Washington, D.C., February.

Jordá, Ó. and A. M. Taylor (2009), "The carry trade and fundamentals: nothing to fear but fear itself", NBER Working Paper, No. 15518, Cambridge, Massachusetts, National Bureau of Economic Research (NBER).

Keynes, J. M. (1936), The General Theory of Employment, Interest and Money, London, Macmillan.

Kuczynski, P. and J. Williamson (2003), After the Washington Consensus. Restarting Growth and Reform in Latin America, Washington, D.C., Institute for International Economics.

López-Mejía, A. (1999), "Large capital flows: causes consequences and policy responses", Finance and Development, Washington, D.C., International Monetary Fund, September.

Magud, N. and C. Reinhart (2006), "Capital controls: an evaluation", NBER Working Paper, No. 11973, Cambridge, Massachusetts, National Bureau of Economic Research (NBER).

Mold, A. and C. A. Rozo (2006), "Liberalization, growth and welfare: the Maquilizacion of the Mexican economy", Trade, Growth, and Inequality in the Era of Globalization, K. Sharma and O. Morrissey (eds.), London, Routledge. 
Monroy, M. (2011), "Industriales piden frenar al súper peso”, Expansión, 21 January [online] http://www. cnnexpansion.com/economia/2011/01/21/Industriales-piden-frenar-al-súper-peso.

Nugée, J. (2004), "Manejo de reservas de oro y de divisas", Ensayos, No. 71, Mexico City, Centre for Latin American Monetary Studies (CEMLA).

Ostry, J. and others (2010a), "Capital inflows: the role of controls", IMF Staff Position Note, No. SPN/10/04, Washington, D.C., International Monetary Fund (IMF).

(2010b), "Entradas de capital: el papel de los controles", Revista de Economía Institucional, vol. 12, No. 23.

Pérez, C. (2010), "Peligro: guerra de divisas", El País, 10 October.

Piz, V. F. (2011a), "Apreciación del tipo de cambio, manejable”, El Financiero, 7 April. (2011b), "México, imán de dólares", El Financiero, 27 April.

Rodrik, D. (2010), "The end of an era in finance" [online] http://www.project-syndicate.org/commentary/ rodrik41/English.

(2006), "The social cost of foreign exchange reserves", NBER Working Paper, No. 11952, Cambridge, Massachusetts, National Bureau of Economic Research (NBER).

Rozo, C. A. (2009), "Apertura, tratados de libre comercio y expectativas frustradas de crecimiento", Fin de época: de la integración tradicional al regionalismo estratégico, A. Guerra-Borges (coord.), Mexico City, Siglo XXI.

Santaella, J. (2010), "Manejo de reservas internacionales y mercado cambiario", Mexico City [online] http:// observatorio.azc.uam.mx/pdf/CBM_8_6_2010_8.pdf.

Stiglitz, J. (2010), "No es momento para una guerra comercial", El País, 2 May [online] http://elpais.com/ diario/2010/05/02/negocio/1272806074_850215.html.

The Economist (2012), "Hitched to the China wagon", 25 August.

Williamson, J. (1990), "What Washington means by policy reform", Latin American Adjustment: How Much has Happened?, J. Williamson (ed.), Washington, D.C., Institute for International Economics. 